\title{
SEEDS OF SOCIAL AND SOLIDARITY ECONOMY IN HUNGARIAN
}

RURAL AREAS

\section{A SZOCIÁLIS ÉS SZOLIDÁRIS GAZDASÁG CSÍRÁI A MAGYARORSZÁGI VIDÉKI TÉRSÉGEKBEN}

Éva G. Fekete, Prof. Dr., Head of Department of Labour and Social Economy University of Miskolc

Address: $\quad 3515$ Miskolc, Egyetemváros, Hungary

Phone: $\quad 36(46) 565111 / 20-23$

E-mail: $\quad$ fekete.eva@uni-miskolc.hu 


\title{
A SZOCIÁLIS ÉS SZOLIDÁRIS GAZDASÁG CSÍRÁI A
}

MAGYARORSZÁGI VIDÉKI TÉRSÉGEKBEN

\section{SEEDS OF SOCIAL AND SOLIDARITY ECONOMY IN HUNGARIAN \\ RURAL AREAS}

Keywords: social innovation, social enterprises, social cooperatives, rural development

\begin{abstract}
The social and solidarity economy (SSE) is an emerging sector of the European economies. It's importance is demonstrated by millions of employees and significant share of GDP. In recognition of its perceptivity, ministries dedicated to SSE have been established in many countries. However, there is a lively debate about on the definition of SSE itself. Opinions on the role of employment, the relations to governments and attitudes to competitiveness differ from each other. In the first part of my paper a clarification of the conceptual issues will be summarized. After that we may follow our investigations on SSE in two directions. First, we will see the special appearance of the SSE in rural areas and then the situation in Hungary will be presented. As an intersection of this two lines, SSE initiatives in the Hungarian rural areas will be discussed. We can speak about the role of the social land programs, the cooperatives, the LEADER groups and the "START" public work in building SSE in the Hungarian rural space.
\end{abstract}

Kulcsszavak: társadalmi innováció, társadalmi vállalkozások, szociális szövetkezet, vidékfejlesztés

\section{Kivonat}

A szolidáris és szociális gazdaság (SSE) Európában is a gazdaság egy feltörekvő ágazata. Bizonyítja ezt a több millió foglalkoztatott és egyes országos GDP-jéböl való jelentős részesedése. Több országban jelentőségét saját minisztérium létrehozásával is elismerték. Ugyanakkor élénk viták léteznek még magáról a szociális gazdaság értelmezéséről is. Eltérnek a vélemények a foglalkoztatási szerep, a kormányzati kötődés, versenyképesség hangsúlyozásáról. A cikk első részében a szolidáris és szociális gazdaság általános fogalmi kérdéseit próbálom tisztázni. Ezt követően vizsgálatainkat két irányban mélyítjük el. Egyrészről a SSE vidéki térségekben való megjelenéséről, másrészről a magyarországi helyzetről, majd a kettő metszeteként a vidéki Magyarországon beazonosítható SEE kezdeményezésekről kívánok szólni. Ez utóbbiak között beszélhetünk a szociális földprogramok, a szövetkezetek, a LEADER csoportok és a START közmunka programok szerepéról a szolidáris gazdaság építésében.

\section{BEVEZETÉS}

A szolidáris és szociális gazdaság Európában úgy a foglalkoztatottak száma, mint a GDPből való részesedése alapján, a gazdaság feltörekvő ágazata. Ugyanakkor élénk viták léteznek még magáról a szociális gazdaság értelmezéséről is. Eltérnek a vélemények a foglalkoztatási szerep, a kormányzati kötődés, versenyképesség hangsúlyozásáról. A magyarországi gyakorlatban gyakori a téves fogalomhasználat, a szociális, vagy inkább társadalmi gazdaság és a társadalmi innovációk értelmezése és a kettő egymáshoz való kapcsolódása sem tisztázott. Éppen ezért jelen cikkben kitüntetett figyelmet fordítunk az 
alapfogalmak tisztázására, a fogalmak rendszerében a magyarországi szolidáris és szociális gazdaság (SSE) kezdeményezések elhelyezésére. Különösen a szociális szövetkezetek, mint a Magyarországon létező egyetlen direkt társadalmi vállalkozási forma, vidékfejlesztésben várható szerepét vesszük górcső alá.

\section{TÁRSADALMI INNOVÁCIÓ ÉS SZOCIÁLIS SZÖVETKEZETEK}

\section{A társadalmi innováció és a társadalmi vállalkozás értelmezése}

Az innováció fogalmának meghatározására adott klasszikus (új termékek, új eljárások, új piacok, új erőforrások, új szervezet) schumpeteri definíció (Schumpeter 1939) mellett létezik egy rövid, frappáns megfogalmazás is: új elképzelés, ami müködik (Mulgan 2006). Ez a rövid megfogalmazás is tartalmazza az innováció két legfontosabb tulajdonságát: az újdonságot és a már megvalósultságot, valamint lehetőséget ad az innováció fogalmának lehető legszélesebb körben történő kiterjesztésére. A gazdaságra vonatkozó, döntően a vállalatok $\mathrm{K}+\mathrm{F}$ tevékenységében realizálódó, technológiai, marketing vagy szervezeti megújuláshoz vezető innovációk mellett a társadalmi tartalmú innováció fogalma is értelmezhető. Így van értelme a társadalom, az azt alkotó és működtető struktúrák, a társadalom intézményeinek megújításáról beszélni. Ezek a gazdaság számára sem érdektelenek, sőt igazából a társadalom és gazdaság kölcsönhatásai fontosságának, a gazdaságra hatással lévő társadalmi tényezők jelentőségének (újra)felfedezése helyezte a tudományos gondolkodás fókuszába a társadalom müködésének megújítására bevezetett új elképzeléseket (partnerség, jó kormányzás, kommunikáció, társadalmi mozgalmak). Ez még azonban nem egyenlő a társadalmi innovációval. Ez utóbbiak gyökere alapvetően a 20.század végére megváltozott gazdasági környezetben, a gazdaság szereplői számára megjelenő új kihívásokban ered. A globalizált versenyben megkövetelt állandó tudásnövelési kényszer, az eddig elhanyagolt területiség, környezeti fenntarthatóság és a fokozódó társadalmi problémák (foglalkoztatás, szegénység) érték, ill. paradigmaváltáshoz vezetett. A gazdasági növekedés helyett az integrált fejlődés került az előtérbe. Nem csupán a társadalmi jól-lét erősítéséhez, de a gazdasági vállalatok prosperitásának biztosításához is szükségessé vált a társadalmi tényezők fejlesztése, a társadalmi erőforrások (társadalmi tőke, hálózatok, társadalmi részvétel, önkéntesség, szabad felhasználású szellemi termékek, helyi tudás) bevonása. A profit-orientált gazdaság és a szükülő költségvetési keretekkel szembe nézni kénytelen, meglehetősen rugalmatlan kormányzati szektor által kielégíteni nem tudott, egyre diverzebb szükségletek a civil 
társadalmat cselekvésre serkentették. Új működő elképzelések (innovációk) sora jelent meg a lefedetlen szükségletek lefedésére. A társadalmi innováció egyszerre jelentheti a gazdaság müködésébe a társadalmi erőforrások bevonását (ami a korábbiakhoz képest egy új dolog) és a társadalmi igények kielégítését célzó innovatív, elsődlegesen társadalmi célokkal rendelkező szervezetek által kifejlesztett és terjesztett új megoldásokat. Az utóbbi gyakorlatilag magába foglalja az előbbit.

A társadalmi vállalkozásoknak három definíciójával találkozhatunk Magyarországon.

1. $\mathrm{NESsT}^{35}:$ (1) innovatív megoldás a társadalmi problémákra, (2) kettős cél: pénzügyi fenntarthatóság javítása, és jelentős társadalmi hatás elérése, (3) jó minőségű termékek és szolgáltatások eladása folyamatos felelős hozzáállással (non-profit, köz-, és üzleti szervezetek egyaránt lehetnek, hátrányos helyzetű emberekhez kötődő társadalmi célokat preferálnak. (Tóth et al. 2011)

2. TÁMOP ${ }^{36}$ Kézikönyv (EU Fehér Könyv alapján): (1) nem kormányzati szervek, (2) elsődlegesen önfoglalkoztatást célzó piaci termelés, kereskedelmi és szolgáltató tevékenységek, (3) alapértékek: önkéntesség, együttmüködés, szolidaritás és felelősség, (4) profitszétosztás tilalma, (5) társadalmi elkötelezettség. (munkanélküliség csökkentése és a segélyezés csökkentése a preferált cél.) (Petheő et al. 2010)

3. Conscise kutatási program ${ }^{37}$ : (1) non-profit szervezet; (2) társadalmi célokat szándékozik megvalósítani üzleti tevékenységeken keresztül; (3) magánszemélyek számára nem engedi a vagyon szétosztását, az a társadalmi cél szerinti célcsoport javát szolgálja, (4) önkéntességen alapuló intézményi struktúrában valósul meg; (5) támogatja a kölcsönösen előnyös együttműködést az adott ágazatban működő más szervezetekkel. (Petheő 2009)

Mindezek mellett, a leggyakoribb a fogalom definíció nélküli használata, esetleg a társadalmi vállalkozásként való működés tudatosulásának hiánya.

Az Európai Bizottság a 2011-ben elfogadott Social Business Initiative intézkedéscsomagban a társadalmi vállalkozások sorába az alábbiakat sorolja:

- az üzleti tevékenységüket a közösség javát szolgáló szociális vagy társadalmi cél érdekében, gyakran magas szintü társadalmi innováció formájában végzik,

- a profitot eme társadalmi cél elérése érdekében visszaforgatják

- a szervezeti és tulajdoni forma visszatükrözi küldetésüket,

\footnotetext{
${ }^{35}$ Nonprofit Enterprise and Self-Sustainability Team (Magyarországon 2001 óta) http://www.nesst.org/hungary/

36 magyarországi Társadalmi Megújulás Operatív Program a 2007-13 közötti programozási időszakban

${ }^{37}$ The Contribution of Social Capital in the Social Economy to Local Economic Development in Western Europe 2000-2003
} 
- demokratikus vagy részvételi alapelvekre épülnek vagy a társadalmi igazságosságra összpontosítanak.

Így

- sérült személyek számára szociális szolgáltatásokat, vagy más árukat és szolgáltatásokat nyújtó vállalkozások (lakhatás, egészségügyi ellátás, idősek vagy fogyatékkal élök segítése, hátrányos helyzetü csoportok befogadása, gyermek gondozás, munkához és képzéshez hozzáférés, függőség menedzsment, stb

- termékeket és szolgáltatásokat valamilyen társadalmi céllal előállító vállalkozások (hátrányos helyzetű, különösen alacsony képzettségü, vagy kirekesztődéshez vezető társadalmi és foglalkozási problémákkal küzdő emberek társadalmi és szakmai integrációt célzó foglalkoztatása).

A társadalmi vállalkozások által alkotott társadalmi gazdaság az EU-ban több mint 11 millió embert, az összes foglalkoztatott mintegy 6\%-át foglalkoztatja. (EC 2011)

Magyarországon a társadalmi vállalkozásokat egységesen szabályozó jogszabály nincs. (Európa legtöbb országában létezik „social enterpise” törvény.) A társadalmi szervezetekröl $^{38}$, a non-profit szervezetek gazdálkodásáról ${ }^{39}$, az önkéntességről ${ }^{40}$ és a szociális szövetkezetekröl ${ }^{4142}$ szóló törvények jelölik ki a jogi kereteket.

A társadalmi vállalkozások kapcsán három veszélyre hívhatjuk fel a figyelmet. A küldetéséből adódóan a társadalmi vállalkozás a közösség számára kíván előnyöket nyújtani, és a társadalom is egyfokú önfeláldozást vár el tőlük. Túlzott jótékonyság és önfeláldozás esetén azonban könnyen eléghetnek, megsemmisülhetnek - mint Prométheusz. Amennyiben a vállalkozói oldal eluralkodik, amellett, hogy a társadalmi cél ködbe vész, amolyan Trójai faló módjára, a térségben müködő vállalkozásokat is tönkre teheti. Ha pedig a kormányzattól, önkormányzattól nem tud leszakadni, az eredeti közösségi célokat veszélyeztető, ill. hosszú távon fenntarthatatlan Frankestein figura válik belőle. (McMurtry 2013)

\footnotetext{
38 2011. évi CLXXV. törvény az egyesülési jogról, a közhasznú jogállásról, valamint a civil szervezetek müködéséről és támogatásáról

${ }^{39}$ 2006. évi IV. törvény a gazdasági társaságokról

${ }^{40} 2005$. évi LXXXVIII. törvény a közérdekű önkéntes tevékenységröl

41 2006. évi X. törvény a szövetkezetekről

${ }^{42}$ 2013. évi XLI. törvény a szociális szövetkezetekkel összefüggésben egyes törvények, továbbá a közfoglalkoztatáshoz kapcsolódó egyes törvények módosításáról
} 
A szociális szövetkezet a társadalmi vállalkozások egyike. Ennek megfelelően üzleti tevékenységet végez, de a társadalmi cél az elsődleges és nincs profitmegosztás a tagok között. Annyiban speciális társadalmi vállalkozási forma, hogy érvényesek rá a szövetkezeti alapelvek (ICIC 1996), azaz:

1. Önkéntes és nyitott tagság: önkéntes szervezetek, melyek nyitva állnak - nemi, társadalmi, faji, politikai, vagy vallási megkülönböztetés nélkül - mindenki számára, akinek hasznára lehetnek szolgáltatásai, és aki elfogadja a tagsággal járó felelősséget.

2. Demokratikus tagi ellenörzés: A szövetkezetek a tagok által ellenőrzött demokratikus szervezetek, a tagok tevékenyen részt vesznek a vezetés és a döntéshozás folyamatában. A megválasztott képviselők (férfiak és nők) a tagságnak felelősek. Az elsődleges szövetkezetekben a tagok egyenlő szavazati jogokat élveznek (egy tag-egy szavazat) és a más szinten müködő szövetkezetek is demokratikusan szerveződnek.

3. A tagok gazdasági részvétele: A tagok igazságosan járulnak hozzá a szövetkezetük vagyonához és azt demokratikusan ellenőrzik. Rendszerint a szövetkezet tőkéjének legalább egy része a szövetkezet közös tulajdonát képezi. A tagság feltételeként előírt nagyságú jegyzett tőke után - ha erre egyáltalán sor kerül - a tagok általában korlátozott mértékű ellenszolgáltatásban részesülnek. A profitból legfeljebb az elvégzett munka (és nem a tőke) arányában részesednek.

4. Autonómia és függetlenség: A szövetkezetek a tagok által ellenőrzött autonóm, önfenntartó szervezetek. Amennyiben megállapodást kötnek más szervezetekkel, beleértve a Kormány hatáskörébe tartozókat is, vagy külső tőkeforrásokat használnak fel: mindezt csak olyan feltételek mellet tehetik, hogy egyidejüleg biztosítják a demokratikus tagi ellenőrzést és a szövetkezeti autonómia fenntartását.

5. Oktatás, képzés és tájékoztatás: A szövetkezetek olyan oktatást és képzést nyújtanak tagjaiknak, választott képviselőiknek, vezetőiknek, valamint alkalmazottaiknak, aminek alapján azok hatékonyan hozzájárulhatnak szövetkezetük fejlesztéséhez. A szövetkezetek tájékoztatják a nyilvánosságot, különösképpen a fiatalokat és a közvéleményalakítókat a szövetkezeti összefogás jellegéről és előnyeiről.

6. Szövetkezetek közötti együttmüködés: A szövetkezetek helyi, nemzeti, területi és nemzetközi együttmüködés révén szolgálják a leghatásosabban tagságukat és erösítik a szövetkezeti mozgalmat. 
7. Közösségi felelösség: A szövetkezetek tagjaik által elfogadott elvek alapján közösségük folyamatos és tartós fejlődésének a fenntartásán munkálkodnak.

Nem minden szövetkezet társadalmi vállalkozás (ennek megítélése a szakirodalomban vitatott) és nem minden társadalmi vállalkozás szövetkezet (lehet egyesület, alapítvány, kölcsönös előnyökön alapuló társaság is).

\section{Szociális szövetkezetek Magyarországon}

A magyarországi szabályozásban a rendszerváltást követően a szociális szövetkezetek először 2006-ban jelentek meg. Eszerint: a szövetkezet az alapszabályban meghatározott összegű részjegy-tőkével alapított, a nyitott tagság és a változó tőke elvei szerint működő, jogi személyiséggel rendelkező szervezet, amelynek célja a tagjai gazdasági, valamint más társadalmi (kulturális, oktatási, szociális, egészségügyi) szükségletei kielégítésének elősegítése. Szociális szövetkezet estén a cél a hátrányos helyzetben lévő tagok számára munkafeltételek teremtése, valamint szociális helyzetük javításának egyéb módon történő elősegítése.

A szövetkezet minden olyan tevékenységet folytathat, amelyet törvény szövetkezet számára nem tilt.

Főtevékenységét tekintve lehet:

a) tagjai számára beszerzéssel, tagjai termékeinek feldolgozásával, értékesítésével foglalkozó szövetkezet;

b) tagjai termelését elősegítő szövetkezet;

c) közös termelést megvalósító szövetkezet;

d) tagjai fogyasztását elősegítő szövetkezet;

e) tagjainak munkafeltételeket teremtő, illetőleg szociális helyzetüket más módon javító, valamint iskolaszövetkezetként müködő szociális szövetkezet;

f) tagjai számára külön törvény szerint közhasznú tevékenységnek minősülő feladatokat ellátó, külön törvény szerint közhasznú szervezeti jogállással rendelkező szociális szövetkezet.

2013.szeptember 1-től a szociális szövetkezetek egy új formája jelent meg Magyarországon. ${ }^{43}$ Ennek legjellemzőbb sajátosságai:

Új szereplők a tagok között:

43 2013. évi XLI. törvény a szociális szövetkezetekkel összefüggésben egyes törvények, továbbá a közfoglalkoztatáshoz kapcsolódó egyes törvények módosításáról 
- A természetes személy tagokon kívül helyi önkormányzat vagy nemzetiségi önkormányzat, illetve ezek jogi személyiségű társulása, jogszabályban meghatározott karitatív tevékenységet ellátó közhasznú jogállású szervezet is tag lehet, ez utóbbiak lehetnek befektető tagok.

- A közfoglalkoztatásért felelős miniszter haszonkölcsön szerződés esetén, annak lejártáig állami képviselőt rendelhet ki.

Belépés megkönnyítése:

- a belépni kívánó tag részjegy jegyzési kötelezettségének a más tagtól való megvásárlásra tett szándéknyilatkozattal is teljesíthető, vagyoni hozzájárulását egy éven belül kell a szövetkezet rendelkezésére bocsátania, ezt megteheti a szövetkezetben végzett munkavégzése során megtermelt és tulajdonába kerülő javak átadásával is.

Tagi munkavégzési jogviszony létrehozása:

- tagi munkavégzési jogviszony önálló, más munkavégzésre irányuló jogviszonyt szabályozó törvény hatálya alá nem tartozó jogviszony, amelyben az elvégzett munka ellentételezése a tagi munkavégzés arányában részben vagy egészben a közösen megtermelt javak természetben történő átadásával is történhet. Erre a jogviszonyra speciális adó- és járulékfizetési szabályok vonatkoznak, valamint nem érinti a munkavégző segélyekre, egyéb támogatásokra való jogosultságát.

Átmenet biztosítása a közfoglalkoztatásból:

- Amennyiben több hátrányos helyzetủ személy egy közfoglalkoztatónál áll legalább egyéves időtartamban közfoglalkoztatási jogviszonyban, és a közfoglalkoztatottak vállalják, hogy szociális szövetkezet tagjaként a továbbiakban legalább két évet együtt fognak dolgozni, a közfoglalkoztatás során használt ingó tárgyi eszközöket az általuk megalapított szociális szövetkezet a közfoglalkoztatótól haszonkölcsönszerződés alapján ingyenesen használatba veheti.

\section{A vidék lehetséges társadalmi innovációi}

A kimondottan vidéki térségekben jellemző társadalmi innovációkat a vidék sajátosságaiból vezethetjük le.

Ezek a sajátosságok: 
- alacsony koncentráció (népességben, vállalkozásokban, épületekben): a méretgazdaságossági elvek szigorú alkalmazása esetén az alacsony koncentráció a szolgáltatások hiányos kiépültségéhez vezetett,

- természethez való közelség, ami egyben erőforrásként hasznosítható érték és súlyos felelősség,

- centrumoktól való távolság, ami információs elzártságot, magára hagyatottságot, a magasabb szintű szolgáltatások nehezebb elérhetőségét,

- lassabb kulturális változások, melyek kedveznek a kulturális értékek megőrzésének, de egyben az innovációk terjedését is lassítják. (G.Fekete 2011)

A fentiekből következően az alábbiakban határozhatók meg a társadalmi innováció potenciális területei (a lehetséges társadalmi célok) a vidéki térségekben. (1.táblázat)

1.táblázat: A társadalmi innováció potenciális területei vidéki térségekben

\begin{tabular}{|c|c|c|}
\hline vidéki sajátosság & társadalmi cél & sajátos feladat \\
\hline \multirow[t]{2}{*}{$\begin{array}{l}\text { alacsony } \\
\text { koncentráció }\end{array}$} & $\begin{array}{l}\text { depriváció csökkentése } \\
\text { felzárkózás }\end{array}$ & $\begin{array}{l}\text { alternatív (kisléptékü) szolgáltatási módok } \\
\text { bevezetése: oktatás, müvelődés, egészségügy, } \\
\text { szociális gondoskodás, kommunális } \\
\text { szolgáltatások }\end{array}$ \\
\hline & $\begin{array}{l}\text { területi és társadalmi } \\
\text { integráció }\end{array}$ & $\begin{array}{l}\text { együttmüködések és integrációk szervezése, } \\
\text { belső hálózatok építése, horizontális } \\
\text { közlekedés javítása }\end{array}$ \\
\hline \multirow[t]{2}{*}{ természetközelség } & $\begin{array}{l}\text { egészséges lakókörnyezet } \\
\text { biztosítása a jövő } \\
\text { generációinak is }\end{array}$ & $\begin{array}{l}\text { környezeti fenntarthatóság erősítése: } \\
\text { természetvédelem, tájfenntartás, erdősítés, } \\
\text { alternatív energiaforrások használata, } \\
\text { hulladékkezelés, lakások felújítása, település- } \\
\text { karbantartás }\end{array}$ \\
\hline & $\begin{array}{l}\text { megélhetés biztosítása, } \\
\text { önrendelkezés erösítése, } \\
\text { fiatalok letelepedése }\end{array}$ & $\begin{array}{l}\text { helyi (természeti és kulturális) erőforrások } \\
\text { hasznosítása: tájjellegü élelmiszertermelés, } \\
\text { rekreációs lehetőségek bővítése, } \\
\text { lakóingatlanok kiajánlása }\end{array}$ \\
\hline \multirow[t]{3}{*}{$\begin{array}{l}\text { lassabb kulturális } \\
\text { változások: }\end{array}$} & $\begin{array}{l}\text { tudástársadalomhoz } \\
\text { kapcsolódás elősegítése }\end{array}$ & $\begin{array}{l}\text { tudáskészlet bővítése: helyi tudás, szaktudás, } \\
\text { digitális írástudás fejlesztése (képzések) }\end{array}$ \\
\hline & $\begin{array}{l}\text { identitás megőrzése, } \\
\text { erőforrás-bővítés }\end{array}$ & $\begin{array}{l}\text { kulturális örökség őrzése, hagyományápolás: } \\
\text { gyüjtés, bemutatás }\end{array}$ \\
\hline & $\begin{array}{l}\text { közvetlen részvétel elérése, } \\
\text { kapacitásbővítés }\end{array}$ & jó kormányzás: közösségek erősítése \\
\hline $\begin{array}{l}\text { centrumoktól való } \\
\text { távolság }\end{array}$ & $\begin{array}{l}\text { területi } \quad \text { hátrányok } \\
\text { mérséklése }\end{array}$ & $\begin{array}{l}\text { város-vidék kapcsolatok erősítése: ingázás } \\
\text { segítése, piacok elérése és szervezése, } \\
\text { (fizikai, információs, társadalmi) hálózatok } \\
\text { építése, jelenlét és reprezentáció a városi, } \\
\text { térségi véleményformálásban a én és } \\
\text { döntéshozásban. }\end{array}$ \\
\hline
\end{tabular}

Forrás: saját szerkesztés 


\section{Társadalmi innovációs kezdeményezések (jó gyakorlatok) vidéki térségekben}

A legjobb példák integrált megközelítésủek, de általában ezen belül is kiragadható egy fő motívum. Így vannak a gazdaságra, a szolgáltatások elérhetőségére és az épített környezetre fókuszáló kezdeményezések. Az elválasztás sokszor esetleges, hiszen egy társadalmi innovációs projekt annál hatásosabb, minél több társadalmi célt szolgál, ill. ha ki tudja használni a szinergiát.

Megélhetést segítő kezdeményezések: Önellátó falu (Túristvándi ${ }^{44}$, Belecska) ${ }^{45}$, Közösségi támogatású mezőgazdálkodás (USA-Wisconsin) ${ }^{46}$, Közösségi erdészet (Nagy-Britannia) ${ }^{47}$, Vidéki termékek városi boltja (Portugália) ${ }^{48}$, Mezőgazdasági termékek értékesítése (Írország) $^{49}$, Munkanélküli nőket foglalkoztató textilipari szövetkezet (Spanyolország) ${ }^{50}$ Biogazdálkodás (Hernádszentandrás) ${ }^{51}$.

Szociális szolgáltatások: Szociális bolthálózat (Franciaország) ${ }^{52}$, Faluétterem (Belgium) ${ }^{53}$, Szolgáltatás-jegyrendszer (Belgium) $)^{54}$, Közösségi játszó-csoportok (Nagy-Britannia) ${ }^{55}$, (nem vidéki: Senior Mentor Program (Budapest) ${ }^{56}$ ).

\section{Infrastruktúrát javitó szolgáltatások: Közösségi közlekedés (Nagy-Britannia) ${ }^{57}$,} Hulladékgyüjtés és újrahasznosítás (India) ${ }^{58}$, Alternatív energiaforrások hasznosítása (Németország) $^{59}$, Tájdoktorok és útdoktorok (Antwerpen) ${ }^{60}$.

\footnotetext{
${ }^{44}$ Rácz Katalin (2013) Önellátó és önfenntartó falutípusok a nemzetközi és hazai gyakorlatban. (előadás) „Önfenntartó Falu - Fenntartható Vidék" Jó gyakorlatok és modellek a Kárpát-medencében c. Konferencia Nemzetstratégiai Kutatóintézet, Budapesrt 2013. október 03.

${ }^{45}$ Kabai Gergely-Németh Nándor (2011): Szociális gazdasági törekvések Belecskán. in: A helyi kezdeményezésủ gazdaságfejlesztési programok vizsgálata. Esettanulmányok. (szerk.: Németh Nándor) MTA Közgazdaságtudományi Intézet Budapest, 17-54.

${ }^{46}$ G.Fekete Éva (2001): Innovációk a kistérségi fejlesztésekben. Együtt! De hogyan? MTA RKK, Miskolc-Pécs 85-87.

47 Slee, B. - Clark, G.M. - Snowdown, P. (1966): The Scope for Community Participation in Forest Management. Summary Report. Department of Agriculture, Department of Land Economy University of Aberdeen.

${ }^{48}$ Rural Portugal Palace - a vidék termékeinek városi üzlete. LEADER + Gyakorlai Példák Európában Magyarországi LEADER Központ 2007. 18-19. http://ec.europa.eu/agriculture/rur/leaderplus/pdf/library/nnudocs/gp_hu.pdf

${ }^{49}$ INFO LEADER Nr. 59-3/98.

${ }^{50}$ LEADER Magazin 1999 Spring no.20.

${ }^{51}$ Varga Mariann (2013): Bioszentandrás. Esettanulmány (kézirat) Miskolci Egyetem, Miskolc

${ }^{52}$ Macfarlane, R. - Laville, J-.L. (1992): Developing Community Partnerships in Europe, New ways of meeting social needs in Europe. London: Directory of Social Change and Calouste Gulbenkian Foundation.

${ }^{53}$ Mathijssen, Carmen (2013): Cooperative social restaurants: An innovative instrument in the fight against poverty in the rural context. 4th CIRIEC Conference: Social economy on the move... at the crossroads of structural change and regulation. OCTOBER 24-26, 2013 Antwerp

${ }^{54}$ Peeters, A., 2006.: The Service Voucher in Belgium, IDEA Consult, Brussels

${ }^{55}$ Macfarlane, R. - Laville, J-.L. (1992): Developing Community Partnerships in Europe, New ways of meeting social needs in Europe. London: Directory of Social Change and Calouste Gulbenkian Foundation.

${ }^{56}$ Civil Vállalkozások Nonprofit kft. http://www.civilvallalkozasok.hu

${ }^{57}$ Macfarlane, R. - Laville, J-.L. (1992): Developing Community Partnerships in Europe, New ways of meeting social needs in Europe. London: Directory of Social Change and Calouste Gulbenkian Foundation.

${ }^{58}$ Dharmadhikary-Yadwadkar, Amita(2013): Can the cooperative be an appropriate model for urban waste collection and disposal in India? A case study of swach, Pune, India 4th CIRIEC Conference: Social economy on the move... at the crossroads of structural change and regulation. OCTOBER 24-26, 2013 Antwerp
} 


\section{A szociális szövetkezetek és a társadalmi innovációk}

A szociális szövetkezetek, mint a társadalmi vállalkozások egy fajtája egyszerre lehet önmagában is társadalmi innováció és innovátor.

Az előbbi akkor teljesül, ha valóban új, az eddig kielégítetlen helyi szükségletek kielégítésére képes szervezet jön létre. Ha csak egy más forma (pl. közmunka) ilyen néven történő átmentéséről, vagy a helyi vállalkozókat, gazdálkodókat a piacról kiszorító kezdeményezésről van szó, nem jogos társadalmi innovációnak tekinteni a szociális szövetkezetet.

A szociális szövetkezet innovátorként, azaz további társadalmi innovációk motorjaként akkor lép fel, ha

a. új, eddig lefedetlen területekre lép be: az elöbbiekben láttuk, hogy ilyen potenciális terület bőségesen, nem csak a mezőgazdálkodáshoz kapcsolódóan akad, vagy

b. új, eddig nem bevont erőforrásokat hasznosít, pl. olyan vevői kört ér el, ahonnan árbevételt korábban nem produkáltak, önkénteseket von be, eddig nem hasznosított magántulajdonú ingatlanokat vesz át, adományt gyüjt), vagy

c. új, eddig nem létező kapcsolatokat, hálózatokat épít ki, jellemző pl. a termelők és a fogyasztók, a városban és a vidéken élők, az épek és a fogyatékkal élők, a különböző generációk közötti kapcsolatok tudatos, a kölcsönös érdekek mellett a szolidaritáson alapuló, a társadalmi tőkét növelő elmélyítése), vagy

d. új, a közösségre építő marketing eszközöket vezet be, vagy

e. új foglalkoztatási, a tagokat és / vagy a célcsoportot előnyhöz juttató más módozatokat fejleszt ki, vagy

f. új szervezeti irányítási módszereket alkalmaz.

Bármelyik esetről is van szó, az tudatos, felkészült menedzsment és erős szakmai segítői hálózat létét feltételezi. Felkészültség és kreativitás hiányában sem új ötletekre, sem azok megvalósulására nem számíthatunk.

\footnotetext{
${ }^{59}$ Lautermann, Christian (2013): Energy cooperatives as entrepreneurial actors of the energy transition. 4th CIRIEC Conference: Social economy on the move... at the crossroads of structural change and regulation. OCTOBER 24-26, 2013 Antwerp

${ }^{60}$ Dielis, Luc \& Waegeman, Annick (2013): Social-business innovation in Antwerp: Innovation and market-oriented thinking in Antwerp's social economy. 4th CIRIEC Conference: Social economy on the move... at the crossroads of structural change and regulation. OCTOBER 24-26, 2013 Antwerp
} 


\section{A társadalmi innovációk és a szociális gazdaság megjelenése}

\section{a 2013-20 közötti időszakra vonatkozó fejlesztéspolitikai dokumentumokban}

Európai Uniós szinten a társadalmi vállalkozások kiemelt prioritást élveznek. Az EU Bizottság által 2011.október végén elfogadott Social Business Initiatives ${ }^{61}$ részeként megjelenő akciótervben 11 pontban határozták meg az európai társadalmi vállalkozások megerősítése és a bennük rejlő lehetőségek teljes kihasználása érdekében teendő lépéseket. Ezek a finanszírozást segítő pénzügyi alapok, így a micro-credit rendszer kiterjesztésére, a társadalmi vállalkozások láthatóvá tételére, a jó gyakorlatok megismertetésére, a jogi környezet javítására, a közbeszerzési eljárásokba való bevonásukra, az állami támogatások egyszerüsítésére vonatkoznak.

A magyarországi dokumentumokban is relatíve sürün megjelenik a szociális gazdaság fogalma, ám meglehetősen zavaros elméleti keretben.

A Partnerségi Megállapodás (2014-20) ${ }^{62}$ tervezetében a foglalkoztatási prioritás kifejtésében, fejlesztési szükségletként tünik fel: „A társadalmi vállalkozások (nonprofit cégek) pénzügyi fenntarthatóságának erősítése a célcsoportra szabott KKV támogatástípusú támogatásokkal, a foglalkoztatási hatás érdekében." (32.oldal) Majd ugyancsak a foglalkoztatási célkitűzések között: ,a szociális gazdaság foglalkoztatásának növelése, a társadalmi vállalkozások támogatása”. Társadalmi vállalkozásokról ennél többször nem is esik szó. A szociális gazdaságot többször említve, de a társadalmi vállalkozásoktól elkülönítve tárgyalják. Az előbbivel a tranzit-és a támogatott, sőt a közfoglalkoztatáshoz kapcsolódó foglakoztatást, míg az utóbbival a non-profit cégeket azonosítják. A korábbi egyoldalú szociális nézőponttal szemben előre lépés, hogy most már a szociális gazdaságot érintő célkitűzéseket a gazdasági operatív program keretei között kívánják kezelni. Az európai uniós akciótervben szereplő kezdeményezések azonban nem jelennek meg a hazai dokumentumban. A „társadalmi innováció” fogalommal sem találkozhatunk.

\section{KÖVETKEZTETÉSEK ÉS DILEMMÁK}

A társadalmi vállalkozások láthatóan a vidék megújításában, a sajátosan vidéki problémák kezelésében fontos szerepet játszhatnak és játszanak ott, ahol már volt idejük kiteljesedni.

\footnotetext{
${ }^{61} \operatorname{COM}(2011) 682$ final 25.11.2011.

62 Magyarország Partnerségi Megállapodása a 2014-20-as fejlesztési időszakra (Tervezet) NGM-NTH Budapest 2013.július 1. http://www.nth.gov.hu/files/download_files/623/PM_tervezet_20130701.pdf
} 
A magyar vidék társadalmi problémáinak kezelésében is innovációt jelenthetnek. A magyarországi gyakorlatot látva, azonban több vitapont is felmerül. Így:

\section{A szociális szövetkezet-e az egyetlen megfelelö társadalmi vállalkozási forma?}

Egyértelműen nem. A nonprofit gazdasági társasági forma időnként alkalmasabbnak tünik. A szociális szövetkezethez elengedhetetlen az önkéntesség, a tagok tulajdonosi szemlélete, a kölcsönös bizalom. Ezek nélkül nem lenne szabad belevágni.

\section{Nem válik-e Prométheuszból Trójai faló, vagy Frankestein?}

Nem felejtendő el, hogy a társadalmi vállalkozás elsősorban vállalkozás, azaz a piacról él. Az állami támogatásoktól való egyoldalú függőség a vállalkozás jellegét megkérdőjelezi. Nálunk az eddigi tapasztalatok alapján nagy a veszélye a tartósan támogatásra szoruló, sőt kimondottan arra épülö, torz (Frankestein-típusú) megoldásoknak. A foglalkoztatási kényszerre adott, a munkanélküliek tömegeit a szociális gazdaságban levezetni szándékozó megoldás - mint annak előjelét jelenleg tapasztaljuk - könnyen eltérít gazdasági racionalitástól. Az állami támogatásnak való megfelelési kényszer pedig a gazdasági fenntarthatóság ellenében hat.

A hazai jogszabályok és a társadalmi vállalkozással járó előnyök relatív alacsony volta miatt, egyelőre kevésbé tünik veszélynek, hogy valós társadalmi céllal nem, vagy csak alárendelten rendelkező vállalkozások tünjenek fel ebben a mezben.

Mindkét veszély-lehetőség a megfelelő szabályozással, a társadalmi vállalkozásokra szabott, a gazdasági fenntarthatóságot és a társadalmi cél kiemelését egyaránt segítő támogatási rendszerrel és a társadalmi tudatosság növelésével kivédhető.

3. Mely területeken (földrajzi és tematikus értelemben) ösztönzi az állam a társadalmi innovációkat?

A társadalmi innovációkban lényegesen nagyobb lehetőség rejlik, mint a képzetlen munkanélküli tömegek foglalkoztatása. A vidéki élet minden területén hozhat új, a vidéken élők életminőségét javító eredményeket. Éppen ezért a társadalmi innováció fogalmának és jelentőségének szakmai és közgondolkodásban való tudatosítását, elfogadtatását követően átfogó, a 3.fejezetben vázolt irányokra kiterjedő ösztönző rendszerre van szükség. Földrajzi értelemben is, a vidéki térségekben élőkre kiható társadalmi innovációk nem csupán a vidéken élőktől várhatók, az egész ország innovátorait szükséges lenne megmozgatni, ügyelve arra, hogy a keletkező innovációk eljussanak a kevésbé innovatív 
vidéki térségekbe is. Ehhez a várost és a vidéket összekapcsoló hálózatok és azok részeként az innovációk adaptációjára felkészült helyi tudás-csoportok alakítandók ki.

\section{Mi a szerepe a társadalmi vállalkozások kialakításában az államnak, az önkormányzatoknak?}

Az állami szerepvállalás mértékének és mikéntjének tisztázása Magyarországon különösen érzékeny kérdés. Az államszocialista rendszerből örökölt, ma ismét erősödni látszó paternalizmus (Tóth 2009, Sik 2010) nem kedvez a társadalmi vállalkozásoknak. Az állam túlzott és direkt szerepvállalását a kormányzati magatartás, a civilekkel szembeni mérhetetlen bizalmatlanság mellett az állampolgári mentalitás, a kezdeményezőkészség hiánya is erősíti. A külföldi példák azt mutatják, hogy mindenhol szükség van az állam, a helyi kormányzat segítségére, ám az nem veheti át a helyi kezdeményezés helyét és társadalmi vállalkozások, különösen szociális szövetkezetek felülről nem szervezhetők. A helyi kormányzatok által szervezett, a települési vagyonra és költségvetésre épülő gazdasági tevékenységek sem tekinthetök szövetkezésnek. A jelenlegi helyi gazdasági és társadalmi feltételek mellett azonban szükség lehet az önkormányzatok aktív részvételével működtetett, ám az igazgatástól elkülönülő, erős társadalmi célokat is megvalósító nonprofit vállalkozásokra. A nem kormányzati társadalmi vállalkozások széles körének kiépülése érdekében azonban az államnak a kormányzás indirekt eszközeivel kellene egyrészről a kezdeményezőkészség megerősítését, másrészről a társadalmi vállalkozások müködési kereteit alakítva azok eredményességét segítenie. Az EU Social Business Initiatives Akciótervben megfogalmazott intézkedések adaptálása jelenthetné az első lépést ebbe az irányba.

\section{SUMMARY}

The social enterprises are playing a very important role in revitalization processes of rural areas where they had enough time to flourish. They may also innovation in solving social problems of the Hungarian rural area. However, some questions have arose during our recent research work.

1. Are social cooperative the only appropriate form to social enterprising?

Clearly not. The non-profit corporate form sometimes seems to be more appropriate. Volunteering, members's ownership approach, mutual trust are essential preconditions for social enterprising. Without having those features should not start any social enterprise activity.

2. No Prometheus will be a Trojan horse or Frankeinstein?

We should not forget that the social enterprises are first of all enterprises, so live from the market. The unilateral dependence from state subsidies can call in question the market character of the supported firms. According to our experiences, long term supported and subsidy based, distorted (Frankeinstein-type) market initiatives have a big chance to be created in Hungary. 
The pressure to improve employment and the strong intention to transform masses of unemployment people to social can easily distract from the economic rationality. The obligation to meet the expectation of sponsors leads against to the economic sustainability.

Enterprise without real social aim or having it only in a subordinate way seems to be less likely in dress of social enterprises, due to the domestic legislation and the relatively small benefit of this business form.

Both dangerous situations can be prevented by creating appropriate regulation and supporting system which highlights economic sustainability and social aims as well as improves social responsibility.

3. In what (geographical and functional) fields does and should the state encourage social innovations? Social innovations have significantly greater opportunities than merely employing unskilled unemployment masses. They can bring new achievements which are able to improve the quality of rural life in all aspects. That is why the awareness and the acceptance of opportunities in social innovation and creation of a system outlined in chapter 3 are needed. In geographical point of view, innovations which effect rural people are not created only by them. It is necessary to mobilize innovators in the whole country, to make sure that innovations will reach the less innovative rural areas, too. To do this, networks connecting cities and countryside as well as local knowledge-groups have to be established and made them ready to create or adapt innovations.

4. What roles do the state and the local governments play in development of social enterprises?

To clarify the state's role and limit of power is a very sensitive question in Hungary. The paternalism - which inherited from the socialist system and seems to strengthen nowadays - is not positive for social enterprises. The state's excessive and direct role is strengthened by an immense governmental distrust of the civilians as well as the lack of the civic initiating capabilities. The foreign examples show that social enterprises need the help of the state and the local government everywhere; but those actors must not take over the role of local initiatives. Social enterprises, especially the social cooperatives cannot be organized from above. Economic activities organized by local governments and built on municipal property and budget may not be considered a cooperation. However, local economic and social conditions may require non-profit businesses with strong social targets and an active participation of local government but they must operate separately from the local administration in all circumstances.

In order to create and strengthen a wide range of non-governmental social enterprises, the state should use indirect tools which are able to improve civic initiating capabilities on one side, and form a beneficial environment for the social enterprises on another side. Adaptation of the formulated measures which are laid down in the EU Action Plan for Social Business Initiatives could be the first step on this way.

\section{IRODALOMJEGYZÉK}

Birkhölzer, K. (2000). A szociális vállalkozások szektora Nyugat-Európában. In: Szomszédsági gazdaságfejlesztés (pp. 40-45.) Budapest: Közösségfejlesztők Egyesülete

Borzaga, C., Spear, R. (2004). Trends and Challenges for Co-operatives and Social Enterprises in Developed and Transition Countries. Trento: Edizioni31

EC (2011). European Social Business Initiative COM(2011) 682 final 25.11.2011.

Futó, P. (ed) (2005). A szociális gazdaság jelene és jövõje Magyarországon. Budapest: NFI G. Fekete, É. (2007). Social Economy as a Tool for the Development of Peripheries. In: Regions in Focus? Annual Conference of Regional Studies Association. Lisbon, Portugal, 2007.04.02-2007.04.05. London: Regional Studies Association

G. Fekete, É. (2010). Szociális gazdaság. In Czene Zsolt - Ricz Judit (eds.), Helyi gazdaságfejlesztés. Ötletadó megoldások, jó gyakorlatok Területfejlesztési Füzetek 2. (pp. 158-189.) Budapest: VÁTI Nonprofit Kft. Területi Tervezési és Értékelési Igazgatóság Stratégiai Tervezési és Vidékfejlesztési Iroda

G. Fekete, É. (2011). Elements of Social and Solidarity Economy (SSE) in the Hungarian Local Development. 'Club of Economics in Miskolc' TMP, 7, 1, 17-27.

ICIC (1996): Background Paper to the Statement on the Cooperative Identity. International Cooperative Information Center. ICA / UWCC In Internet: http://www.wisc.edu/uwcc/icic/issues/prin/21-cent/background.html. Accessed on 10.05.2004. 
Kelen, A. (2010). Social Economy in Contemporary Rural Hungary. Retrieved August 20 2013

http://www.academia.edu/2061665/Social_Economy_in_Contemporary_Rural_ Hungary

McMurtry, J.J. (2013). Prometheus, Trojan Horse or Frankenstein?: The social and solidarity economy as community creation, market wedge, or state monster. Presentation at 4th CIRIEC Conference: Social economy on the move... at the crossroads of structural change and regulation. OCTOBER 24-26, 2013 Antwerp

Monzón, J.L., Chaves, R. (2008). The European Social Economy: Concept and Dimensions of the Third Sector. Annals of Public and Cooperative Economics 79, 34., 549-577.

Mulgan, G. (2006). The Process of Social Innovation. Innovations: Technology, Governance, Globalization, 1, 2, 145-162.

Petheő, A. (2009). Vállalati társadalmi felelősségen túl: a szociális vállalkozás. Ph.D. Dissertation, Budapest

Petheő, A. I., Győri, Zs., Feke, N. (2011). Helyzetelemzés kiterjesztése: Felmérés a TÁMOP 2.4.3/B-2 konstrukcióban nyertes szociális szövetkezetek körében. Budapest: OFA, Retrieved September $15 \quad 2013$ from http://www.szocialisgazdasag.hu/kiadvanyok

Petheő, A. I., Győri Zs., Németh B. - Feke N. (2010). A szociális szövetkezetek müködési modelljének kidolgozása a foglalkoztatás elősegítése érdekében. Budapest: Budapesti Vállalkozásfejlesztési Kutató Intézet Nonprofit Kft.

PK (2013). Projekt Kézikönyv TÁMOP-2.4.3.D-3-13/1 Budapest: Emberi Erőforrások Minisztériuma

Rácz, K. (2009). Útban a szociális gazdaság felé? Beszámoló egy produktív szociálpolitikai program eddigi eredményeiről. Kapocs 42, 3, 1-26.

Schumpeter (1939). Business Cycles. 2 vols. New York: McGraw-Hill.

Sik, D. (2010): A cselekvéskoordináció szerkezetváltása? Kísérlet a rendszerváltás kritikai értelmezésére. Szociológiai Szemle, 20 (1) 74-111.

Simkó, J., Tarjányi, O (2011). Research of Social Cooperatives and Supporting Pograms in Hungary. Summary and recommendations. Budapest: OFA

Tóth, L., Varga, É., Varga, P. (2011). A társadalmi vállalkozások helyzete Magyarországon NESsT Kézikönyv sorozat, Budapest: NESSsT

Tóth, I. Gy. (2009): Bizalomhiány, normazavarok, igazságtalanságérzet és paternalizmus a magyar társadalom értékszerkezetében. In: http://www.tarki.hu/hu/research/ gazdkult/publikacio.html 